\title{
Peningkatan Kualitas Kuat Tekan Produk Scaffold Hidroksiapatit (Ha)-Gelatin-Polivinil Alkohol (PVA) Menggunakan Metode Taguchi
}

\author{
Lia Rahmawati ${ }^{1}$, Sadi $^{2}$, Tri Wibawa ${ }^{3 *}$ \\ 1,2,3 Jurusan Teknik Industri, Universitas Pembangunan Nasional "Veteran” Yogyakarta, Yogyakarta, Indonesia \\ (*122170056@student.upnyk)
}

\begin{abstract}
Abstrak - Kerusakan tulang yang akan terjadi di Indonesia pada golongan tenaga kerja sebesar 67,76\% berupa penurunan massa tulang dan sebesar $28,58 \%$ berupa gangguan kepadatan tulang. Scaffold dapat dijadikan sebagai alternatif dari perawatan penyembuhan kerusakan tulang dalam bentuk perancah berpori $3 D$. Scaffold dapat menyediakan lingkungan yang sesuai untuk regenerasi jaringan tulang. Biomaterial keramik sebagai bahan dasar yang cocok untuk scaffold karena karakteristiknya, namun memiliki kekurangan berupa elastisitas rendah dengan permukaan yang keras dan rapuh. Pada penelitian ini dilakukan penambahan material berupa biomaterial gelatin dan PVA yang mana sangat ideal untuk diferensiasi sel dan kekuatan mekanik dari scaffold. Dalam upaya memperbaiki kualitas produk dan proses pembuatan scaffold, desain eksperimen dengan Metode Taguchi untuk mengetahui parameter yang memberikan nilai kuat tekan yang sesuai dengan tulang manusia. Parameter proses yang digunakan yaitu rasio bubuk hydroxyapatite (HA), rasio bubuk gelatin, dan rasio bubuk polyvynyl alcohol (PVA). Berdasarkan hasil penelitian yang dilakukan parameter proses rasio bubuk hydroxyapatite (HA), rasio bubuk gelatin, dan rasio bubuk polyvynyl alcohol (PVA) sangat berpengaruh terhadap nilai kuat tekan scaffold. Hasil eksperimen konfirmasi diperoleh mean sebesar 3,287 MPa menunjukkan bahwa nilai kuat tekan scaffold berada pada rentan nilai kuat tekan manusia.
\end{abstract}

Kata kunci: gelatin; hidroksiapatit; metode Taguchi; scaffold

\section{PENDAHULUAN}

Pada tahun 2009, World Health Organization (WHO) menyebutkan bahwa sekitar 200 juta orang di seluruh dunia menderita kerusakan tulang dan diperkirakan setiap tahunnya akan meningkat. Sebanyak 6,3 juta orang yang mengalami patah tulang terutama pada bagian panggul dan setengahnya terjadi di Asia pada tahun 2050. Hal tersebut akan mengakibatkan kecacatan hingga kematian (Setiadiputri, 2018). Satu dari empat wanita dan satu dari delapan pria berusia 50 tahun atau lebih menderita osteoporosis (Burden et al, 2021, p.817). Jika proporsi ini diekstrapolasi ke statistik populasi dunia saat ini, lebih dari 228 juta orang dewasa berusia 55 tahun atau lebih akan menderita osteoporosis. Hal ini menunjukkan peningkatan nyata dari perkiraan sebelumnya sebesar 200 juta pada tahun 2006 (Burden et al, 2021, p.818).

Usia $\geq 50$ tahun berisiko 2,6 kali lebih besar untuk mengalami gangguan kepadatan tulang dari yang berusia $<50$ tahun. Massa tulang mulai menurun baik pada pria maupun wanita pada awal 30 tahunan dengan sejumlah kecil pengurangan tulang trabekular pada tulang punggung (Mardiyah \& Sartika, 2014). Badan Pusat Statistik pada Agustus 2020 memiliki data mengenai tenaga kerja. Data tersebut jika dihubungkan dengan pernyataan dari Mardiyah dan Sartika sebelumnya, maka diperoleh gambaran mengenai kerusakan tulang yang akan terjadi di Indonesia. Sebesar $67,76 \%$ dari tenaga kerja yang ada di Indonesia berpotensi untuk mengalami penurunan massa tulang dan sebesar $28,58 \%$ dari tenaga kerja yang ada di Indonesia berpotensi untuk mengalami gangguan kepadatan tulang.

Kemajuan bidang kedokteran dapat membantu dalam mengatasi permasalahan mengenai kerusakan tulang, baik dari segi teknologi maupun material dasar. Penyembuhan dilakukan dengan transplantasi tulang menggunakan metode tissue engineering (rekayasa jaringan) menjadi alternatif dari perawatan konvensional. Rekayasa jaringan menjadi solusi dari permasalahan mengenai kerusakan organ atau jaringan. Biaya pengobatan lebih efektif dari perawatan konvensional karena tidak memerlukan terapi tambahan (Poernomo, 2019). Scaffold dapat memperbaiki kerusakan atau degenerasi jaringan tulang. Bahan untuk pembuatan scaffold menggunakan biomaterial berbahan dasar keramik karena memiliki unsur-unsur yang sama dengan unsur penyusun tulang manusia. Hidroksiapatit (HA) merupakan bahan biokeramik menyerupai gugus senyawa pada tulang, oleh karena itu HA dikenal sebagai material yang biokompatibel namun kekakuan tinggi, elastisitas rendah dengan permukaan keras dan rapuh. Berdasarkan kekurangan tersebut, penelitian ini akan membuat scaffold dari hidroksiapatit dan menambahkan biomaterial alami berupa gelatin dan polyvynyl alcohol (PVA) yang sangat ideal untuk diferensiasi sel dan kekuatan mekanik dari scaffold. 
Penderita kerusakan tulang dan degenerasi tulang akan semakin meningkat setiap tahun sesuai dengan data yang telah disebutkan sebelumnya. Hal ini akan berbanding lurus dengan permintaan kebutuhan scaffold di masa mendatang pada industri kesehatan. Industri kesehatan perlu memperhatikan hal tersebut agar ketersediaan scaffold dapat seimbang dengan kebutuhannya, mengingat scaffold merupakan hal baru dan lebih efektif dari perawatan konvensional. Penelitian dalam bidang ini perlu ditingkatkan lagi tidak hanya dari segi material dan teknologi, melainkan dari segi sifat mekanik yang merupakan persyaratan dalam melakukan implant. Penelitian mengenai uji kuat tekan scaffold perlu dilakukan agar tidak hanya dihasilkan scaffold yang biokompatibel, tetapi juga memiliki nilai kuat tekan yang berada pada rentan nilai kuat tekan tulang manusia.

Pada penelitian ini akan dibuat scaffold dengan menggunakan biomaterial hydroxyapatite (HA) - gelatin polyvynyl alcohol (PVA) dengan tujuan mengetahui formulasi untuk memperoleh nilai kuat tekan yang berada pada rentan nilai kuat tekan tulang manusia. Tujuan tersebut dicapai dengan memilih parameter proses yang dapat mempengaruhi nilai kuat tekan berdasarkan penelitian sebelumnya. Hasil penelitian Narbat, Orang, Hashtjin, \& Goudarzi (2006) menunjukkan bahwa penambahan hidroksiapatit (HA) mempengaruhi sifat mekanik scaffold. Hasil penelitian Kim, Yang, Choi, Cho, \& Kim (2018) menunjukkan bahwa gelatin/PVA berpotensi untuk aplikasi scaffold. Tontowi, Anindyajati, Tangkudung, \& Dewo (2018) mengembangkan material biokomposit hidroksiapatit (HA), gelatin, dan PVA dengan metode freeze-drying. Proses pembuatan menggunakan metode freeze drying karena dapat menghasilkan scaffold dengan porositas yang tinggi (mencapai 90\%) (Fitriyana, 2020).

Perlu dilakukan upaya agar dihasilkan scaffold dengan nilai kuat tekan sesuai manusia dengan perbaikan kualitas produk dan proses pembuatan scaffold. Desain eksperimen dapat mengidentifikasi parameter proses dalam pembuatan scaffold untuk memberikan niai kuat tekan yang sesuai dengan tulang manusia. Nilai optimumnya untuk mengetahui parameter yang memberikan hasil terbaik. Metode Taguchi mampu mengevaluasi beberapa faktor dengan jumlah test yang minimum dengan orthogonal array membantu dalam menentukan tata letak data eksperimen.

\section{STUDI LITERATUR}

\section{A. Scaffold}

Menurut (Herda \& Puspitasari, 2016) scaffold adalah biomaterial solid, porus dan berbentuk 3 dimensi yang didesain berperan untuk mendukung interaksi sel-biomaterial, adhesi sel dan deposisi matriks ekstraseluler, menyediakan suplai gas, nutrisi dan faktor pengaturan sehingga dapat terjadi proliferasi, diferensisasi dan maturasi sel.

\section{B. Metode Taguchi}

Metode Taguchi merupakan metodologi baru dalam bidang teknik yang bertujuan untuk memperbaiki kualitas produk dan proses serta dapat menekan biaya dan resources seminimal mungkin. Sasaran metode Taguchi adalah menjadikan produk rebust terhadap noise karena itu sering disebut sebagai rebust design. Didalam perbaikan kualitas secara esensial Metode Taguchi memakai alat-alat statistik, tetapi Taguchi menyederhanakan dengan mengidentifikasikan beberapa petunjuk yang kuat unutk layout eksperimen dan menganalisi hasilnya (Suryaningsih, 2010).

1. Othogonal Array

Taguchi menggunakan orthogonal array (OA) untuk mendiskripsikan jumlah eksperimental yang dilakukan. Desain OA sering digunakan dalam desain eksperimen dengan multilevel faktor.

2. Karakteristik Kualitas

Karakteristik kualitas (variabel respons) adalah obyek yang menarik dari produk atau proses. Karakteristik kualitas dapat dikelompokkan menurut nilai targetnya sebagai berikut:

Nominal the best

Nominal the best adalah karakteristik kualitas terukur dengan nilai target yang ditentukan secara spesifik. Nilai tersebut dapat positif maupun negatif, yang ditunjukkan pada persamaan 1.

$$
\mathrm{SN}_{\mathrm{NTB}}=10 \log _{10}\left[\frac{\mu^{2}}{\sigma^{2}}\right]
$$




$$
\begin{gathered}
\mu=\frac{1}{n} \sum_{\mathrm{i}=1}^{\mathrm{n}} \mathrm{y}_{\mathrm{i}} \\
\sigma^{2}=\frac{1}{\mathrm{n}} \sum_{\mathrm{i}=1}^{\mathrm{n}}\left(\mathrm{y}_{\mathrm{i}}-\mu\right)^{2}
\end{gathered}
$$

Smaller the better

Smaller the better adalah karakteristik kualitas terukur dengan nilai non-negatif dan targetnya adalah nilai yang sekecil-kecilnya (nol). Yang ditunjukkan pada persamaan 4.

$$
\mathrm{SN}_{\mathrm{STB}}=-10 \log \left[\frac{1}{n} \sum_{i=1}^{n} y_{i}^{2}\right]
$$

Higher the better

Higher the better adalah karakteristik kualitas terukur dengan nilai non-negatif yang mempunyai kondisi ideal dan nilai targetnya adalah nilai yang sebesar-besarnya (tak terbatas) yang ditunjukkan pada persamaan 5 .

$$
\mathrm{SN}_{\mathrm{HTB}}=-10 \log \left[\frac{1}{\mathrm{n}} \sum_{\mathrm{i}=1}^{\mathrm{n}} \frac{1}{\mathrm{y}_{\mathrm{i}}^{2}}\right]
$$

\section{Analisis of Variansi (ANOVA)}

Analisis varian untuk mencari besarnya pengaruh dari setiap parameter kendali terhadap suatu proses. Pada metode Taguchi, analisis varian dapat digunakan sebagai metode statistik untuk menginterpretasikan data-data hasil percobaan (Damayanti, 2017).

\section{METODOLOGI}

A. Waktu Penelitian

Waktu penelitian dilakukan selama 3 bulan, pada April 2021 sampai Juni 2021.

B. Tempat Penelitian

Tempat yang dipakai dalam penelitian ini adalah Laboratorium Fisika Material Universitas Airlangga untuk pembuatan scaffold dan uji kuat tekan.

C. Alat Penelitian

Peralatan yang digunakan dalam penelitian ini timbangan digital, spatula, gelas ukur, gelas backer, stirrer bar, magnetic stirrer, cetakan spesimen, freezer, freezed drying, dan alat uji kuat tekan.

\section{Bahan Penelitian}

Bahan yang digunakan dalam penelitian ini adalah bubuk hydroxyapatite (HA), bubuk gelatin, bubuk polyvynil alcohol (PVA), dan air destilasi.

\section{E. Pengumpulan Data}

Data primer yang digunakan yaitu nilai kuat tekan dari scaffold hydroxyapatite (HA) - gelatin - polyvynyl alcohol (PVA). Data nilai kuat tekan digunakan untuk mengidentifikasi parameter proses yang memberikan nilai optimum sesuai dengan rentan nilai kuat tekan tulang manusia. Data sekunder yang digunakan yaitu level dari parameter rasio bubuk hydroxyapatite (HA), rasio bubuk gelatin, rasio bubuk polyvynyl alcohol (PVA). Data level dari parameter tersebut digunakan sebagai pedoman untuk melakukan prosedur pembuatan scaffold hydroxyapatite (HA)-gelatin-polyvynyl alcohol (PVA). Data tersebut berdasarkan penelitian terdahulu memberikan peningkatan pada nilai kuat tekan dari scaffold. 


\section{F. Metode}

Desain eksperimen dengan metode Taguchi harus dapat menganalisa suatu kondisi untuk memenuhi kondisi terbaik, memperkirakan kontribusi dari tiap faktor, memperkirakan respon atau akibat yang mungkin dari kondisi optimum.

\section{HASIL DAN DISKUSI}

Setelah melalui studi literatur mengenai parameter yang mempengaruhi nilai kuat tekan scaffold, maka didapatkan parameter yang berpengaruh cukup signifikan. Kemudian dijadikan sebagai parameter proses dalam perancangan desain eksperimen yang ditampilkan pada Tabel 1.

Tabel 1

Parameter nilai kuat tekan scaffold

\begin{tabular}{cc}
\hline Kode & Nama Parameter \\
\hline A & Rasio bubuk hydroxyapatite (HA) \\
B & Rasio bubuk gelatin \\
C & Rasio polyvynyl alcohol (PVA) \\
\hline
\end{tabular}

Penentuan nilai setting level didasarkan pada studi literatur. Nilai setting level pada masing-masing parameter ditunjukkan pada Tabel 2.

Tabel 2

Setting level pada parameter

\begin{tabular}{clcc}
\hline Kode & \multicolumn{1}{c}{ Nama Parameter } & Level 1 & Level 2 \\
\hline A & Rasio bubuk hydroxyapatite (HA) & 1 & 2 \\
B & Rasio bubuk gelatin & 1 & 1,5 \\
C & Rasio polyvynyl alcohol (PVA) & 0,15 & 0,30 \\
\hline
\end{tabular}

Orthogonal array (OA) digunakan untuk mengetahui informasi efek parameter yang maksimum dan jumlah eksperimen yang minimum dengan menghitung nilai degree of freedom (DoF). Pada eksperimen ini menggunakan 3 parameter dimana masing-masing parameter memiliki 2 level. Hasil perhitungan nilai degree of freedom (DoF) pada penelitian ini adalah 3 derajat kebebasan. Dalam memilih matriks orthogonal array yang sesuai, maka derajat kebebasan matriks orthogonal array $\geq$ dari derajat kebebasan. Sehingga matriks orthogonal array yang sesuai yaitu $\mathrm{L}_{4}\left(2^{3}\right)$. Karakteristik kualitas Signal to Noise Ratio (SNR) untuk meningkatkan kualitas lewat variasi dan peningkatan pengukuran. Penelitian ini menggunakan karakteristik kualitas Larger the Better.

Tabel 3

Data perhitungan mean dan SNR hasil eksperimen nilai kuat tekan scaffold

\begin{tabular}{ccccccccc}
\hline \multicolumn{1}{c}{ Parameter } & \multicolumn{7}{c}{ Replikasi } \\
Nomor & $\begin{array}{c}\text { Rasio bubuk } \\
\text { Eksperimen } \\
\text { hydroxyapatite } \\
\text { (HA) }\end{array}$ & $\begin{array}{c}\text { Rasio } \\
\text { bubuk } \\
\text { gelatin }\end{array}$ & $\begin{array}{c}\text { Rolyvynyl } \\
\text { alcohol } \\
(\mathrm{PVA})\end{array}$ & $\begin{array}{c}\mathrm{R} 1 \\
(\mathrm{MPa})\end{array}$ & $\begin{array}{c}\mathrm{R} 2 \\
(\mathrm{MPa})\end{array}$ & $\begin{array}{c}\mathrm{R} 3 \\
(\mathrm{MPa})\end{array}$ & Mean & SNR \\
\hline 1 & 1 & 1 & 0,15 & 4,466 & 1,434 & 3,416 & 3,105 & 6,832 \\
2 & 1 & 1,5 & 0,30 & 1,984 & 2,343 & 2,577 & 2,301 & 7,086 \\
3 & 2 & 1 & 0,30 & 1,514 & 1,275 & 1,747 & 1,512 & 3,375 \\
4 & 2 & 1,5 & 0,15 & 2,804 & 1,210 & 1,982 & 1,999 & 4,499 \\
\hline
\end{tabular}

Data respon hasil uji kuat tekan diolah untuk membuat tabel respon kuat tekan rata-rata dari setiap eksperimen. Pengolahan data menggunakan bantuan software MINITAB 20 dan Excel. Hasil pengolahan data respon eksperimen terhadap rata-rata dan SNR ditunjukkan pada Tabel 4 dan Tabel 6 serta Gambar 1 dan Gambar 2. 
Tabel 4

Respon kuat tekan scaffold untuk nilai mean

\begin{tabular}{lccc}
\hline & $\begin{array}{c}\text { Rasio bubuk } \\
\text { hydroxyapatite (HA) }\end{array}$ & $\begin{array}{c}\text { Rasio bubuk } \\
\text { gelatin }\end{array}$ & $\begin{array}{c}\text { Rasio polyvynyl } \\
\text { alcohol (PVA) }\end{array}$ \\
\hline Level 1 & 2,703 & 2,309 & 2,552 \\
Level 2 & 1,755 & 2,150 & 1,907 \\
Difference & 0,948 & 0,159 & 0,645 \\
Ranking & 1 & 3 & 2 \\
\hline
\end{tabular}

Tabel 5

Respon kuat tekan scaffold untuk SNR

\begin{tabular}{lccc}
\hline & $\begin{array}{c}\text { Rasio bubuk } \\
\text { hydroxyapatite (HA) }\end{array}$ & $\begin{array}{c}\text { Rasio bubuk } \\
\text { gelatin }\end{array}$ & $\begin{array}{c}\text { Rasio polyvynyl } \\
\text { alcohol (PVA) }\end{array}$ \\
\hline Level 1 & 6,959 & 5,104 & 5,666 \\
Level 2 & 3,937 & 5,793 & 5,231 \\
Difference & 3,022 & 0,689 & 0,435 \\
Ranking & 1 & 2 & 3 \\
\hline
\end{tabular}

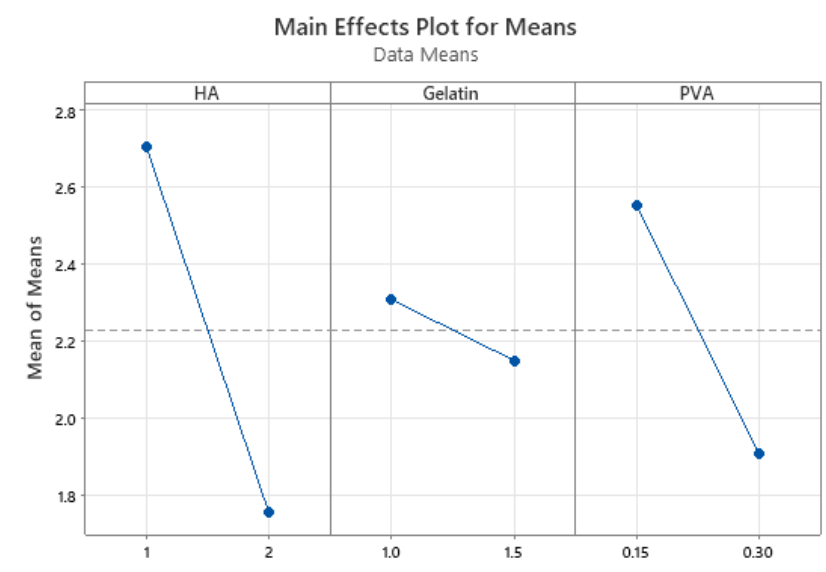

Gambar 1. Grafik respon kuat tekan scaffold untuk Mean

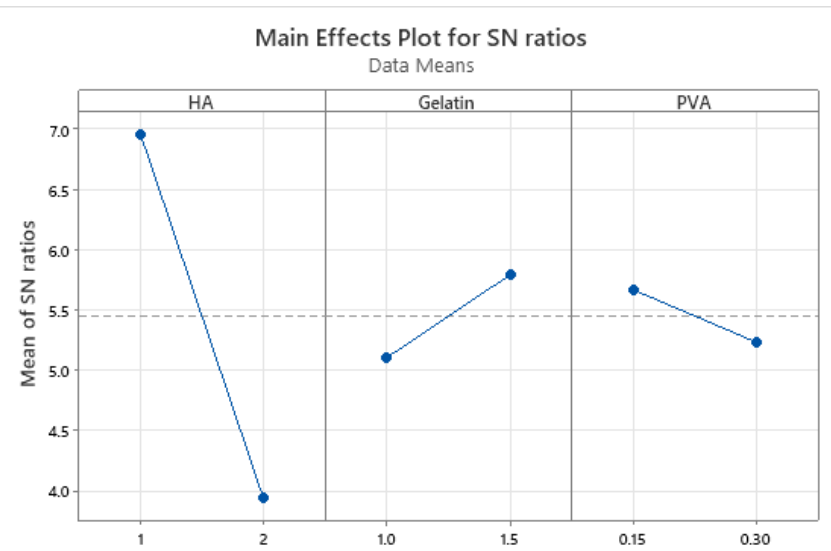

Signal-to-noise: Larger is better

Gambar 2. Grafik respon kuat tekan scaffold untuk SNR 
Tabel 6

ANNOVA mean setelah pooling up

\begin{tabular}{|c|c|c|c|c|c|c|c|c|}
\hline Sumber & Pool & $\mathrm{Sq}$ & $\mathrm{v}$ & $\mathrm{Mq}$ & F-ratio & $\mathrm{Sq}^{\prime}$ & rho $\%$ & F-tabel \\
\hline $\begin{array}{c}\text { Rasio bubuk } \\
\text { hydroxyapatite (HA) }\end{array}$ & & 2,696 & 1 & 2,696 & 3,805 & 1,988 & 19,253 & 5,12 \\
\hline $\begin{array}{l}\text { Rasio polyvynyl } \\
\text { alcohol (PVA) }\end{array}$ & & 1,249 & 1 & 1,249 & 1,763 & 0,541 & 5,238 & 5,12 \\
\hline Pooled e & & 6,377 & 9 & 0,709 & 1 & 7,795 & 75,508 & \\
\hline $\mathrm{St}$ & & 10,323 & 11 & 0,938 & - & 10,323 & 100,000 & \\
\hline Mean & & 59,639 & 1 & - & - & - & - & \\
\hline $\mathrm{ST}$ & & 69,962 & 12 & - & - & - & - & \\
\hline
\end{tabular}

Tabel 7

ANNOVA SNR setelah pooling up

\begin{tabular}{|c|c|c|c|c|c|c|c|c|}
\hline Sumber & Pool & $\mathrm{Sq}$ & $\mathrm{V}$ & $\mathrm{Mq}$ & F-ratio & $\mathrm{Sq}^{\prime}$ & rho $\%$ & F-tabel \\
\hline $\begin{array}{c}\text { Rasio bubuk } \\
\text { hydroxyapatite (HA) }\end{array}$ & & 9,135 & 1 & 9,135 & 48,348 & 8,946 & 91,303 & 5,12 \\
\hline Rasio bubuk gelatin & & 0,474 & 1 & 0,474 & 2,510 & 0,285 & 2,912 & 5,12 \\
\hline Pooled e & & 0,189 & 1 & 0,189 & 1,000 & 0,567 & 5,785 & \\
\hline St & & 9,798 & 3 & 3,266 & - & 9,798 & 100,000 & \\
\hline Mean & & 118,732 & 1 & - & - & - & - & \\
\hline ST & & 128,530 & 4 & - & - & - & - & \\
\hline
\end{tabular}

Berdasarkan tabel respon kuat tekan untuk mean dan SNR dihasilkan level faktor yang optimal yaitu: A (Rasio bubuk hydroxyapatite (HA) 1, B (Rasio bubuk gelatin) 1, dan C (Rasio polyvynyl alcohol (PVA)) 1. Setelah setting level faktor optimal, kemudian mencari nilai prediksi dan selang kepercayaan mean dan SNR. Dari hasil perhitungan mean, prediksi respon mean sebesar 3,026 MPa dan selang kepercayaan proses optimal pada 2,074 Mpa $\leq \mu$ predicted $\leq 3,978 \mathrm{Mpa}$. Dari hasil perhitungan SNR, prediksi respon SNR sebesar 6,615 Mpa dan selang kepercayaan proses optimal pada 1,833 Mpa $\leq \mu$ predicted $\leq 11,397 \mathrm{Mpa}$.

Eksperimen konfirmasi dilakukan pada kombinasi level-level faktor terbaik pada eksperimen Taguchi. Hasil perhitungan dari data-data eksperimen konfirmasi, maka diperoleh mean sebesar 3,287 Mpa dan SNR sebesar 9,439 Mpa. Selang kepercayaan ekperimen konfirmasi untuk mean pada 2,009 Mpa $\leq \mu$ Confirmation $\leq 4,565$ Mpa dan SNR pada -2,095 Mpa $\leq \mu$ Confirmation $\leq 8,670$ Mpa.

\section{KESIMPULAN}

Faktor yang berpengaruh signifikan terhadap nilai kuat tekan scaffold meliputi rasio bubuk hydroxyapatite (HA), rasio bubuk gelatin, dan rasio polyvynyl alcohol (PVA). Hasil eksperimen konfimasi menunjukkan bahwa setting level optimal berada pada rentan nilai kuat tekan tulang canceollus (2-12 MPa). Selang kepercayaan mean dan SNR untuk nilai optimal dan nilai konfirmasi saling berpotongan, sehingga eksperimen pembuatan scaffold dengan rasio bubuk hydroxyapatite (HA) sebesar 1, rasio bubuk gelatin sebesar 1, dan rasio bubuk polyvynyl alcohol (PVA) sebesar 0,15 dapat diterima.

\section{DAFTAR PUSTAKA}

Burden, A., Tanaka, Y., Xu, L., Ha, Y., Closkey, E. M., Cummings, S., \& Gluer, C. (2021). Osteoporosis case ascertainment strategies in European and Asian contries: a comparative review. Osteoporosis International 32, 817-829. doi: https://doi.org/10.1007/s00198-020-05756-8.

Damayanti, Mia Kristina. (2017). Desain Parameter Eksperimen Untuk Optimasi Nilai Frangibility Factor Material Komposit Dengan Metode Taguchi Dan Neural Network. (Skripsi). Institut Teknologi Sepuluh Nopember, Surabaya, Indonesia. 
Fitriyana, Nur. (2020) . Karakteristik Scaffold Dental Gipsum Hidroksiapatit (DGHA) Dengan Kombinasi Silk Fibroin (SF) dan Gelatin (Dengan Metode Freeze Drying). (Skripsi). Universitas Jember, Jember, Indonesia.

Herda, E., \& Puspitasari, D. (2016). Tinjauan Peran Dan Sifat Material Yang Digunakan Sebagai Scaffold Dalam Rekayasa Jaringan. Jurnal Material Kedokteran Gigi, 1(5), 56-63.

Kim, H., Yang, G. H., Choi, C. H., Cho, Y. S., \& Kim, G. H. (2018). Gelatin/PVA Scaffolds Fabricated Using a $3 D$ Printing Process Employed with a Low-Temperature Plate for Hard Tissue Regeneration: Fabrication and Characterization. Internasional Journal of Biological Macromolecules 120, 119-127.

Mardiyah, S., \& Sartika, R. A. (2014). Gangguan Kepadatan Tulang pada Orang Dewasa di Daerah Urban dan Rural. Jurnal Kesehatan Masyarakat Nasional Vol. 8, No. 6, 272 - 279.

Narbat, Mehdi Kazemzadeh, et al. (2006). Fabrication of Porous Hydroxyapatite-Gelatin Composite Scaffolds for Bone Tissue Engineering in Iranian Biomedical Journal 10 (4), 215-223.

Poernomo, H. (2019). TEKNIK BONE TISSUE ENGINEERING (BTE) UNTUK REGENERASI JARINGAN PERIODONTAL DAN ESTETIK PADA EDENTULOUS RIDGE. Interdental Jurnal Kedokteran Gigi (IJKG): Vol.15, No.2, 56-59.

Setiadiputri, J.N.. (2018). Sintesis dan Karakterisasi Biokomposit Hidroksiapatit-Alginat-Zinc Sebagai Bone Graft Untuk Penanganan Bone Defect. (Skripsi). Universitas Airlangga, Surabaya, Indonesia.

Suryaningsih. (2010). Desain Eksperimen Taguchi Dalam Menentukan Penyetelan Mesin Yang Optimal Dalam Proses Pengemasan Creamer Untuk Menghasilkan Kekuatan Seal Yang Terbaik. (Skripsi). Universitas Indonesia, Depok, Indonesia.

Tontowi, A. E., Anindyajati, A., Tangkudung, R., \& Dewo, P. (2018). Biocomposite of Hydroxyapatite/Gelatin/PVA for Bone Graft Application. 1st International Conference on Bioinformatics, Biotechnology, and Biomedical Engineering (BioMIC) (pp. 1-6). Yogyakarta: Universitas Gadjah Mada. 